\title{
NASA Laser Remote Sensing Technology Needs for Earth Science in the Next Decade and Beyond
}

\author{
David M. Tratt and Jon M. Neff \\ The Aerospace Corporation, 200 S. Los Robles Ave., Suite 150, Pasadena, CA, USA 91101 \\ Azita Valinia \\ NASA Goddard Space Flight Conter, Code 600, Greenbclt, MD, USA 20771
}

\begin{abstract}

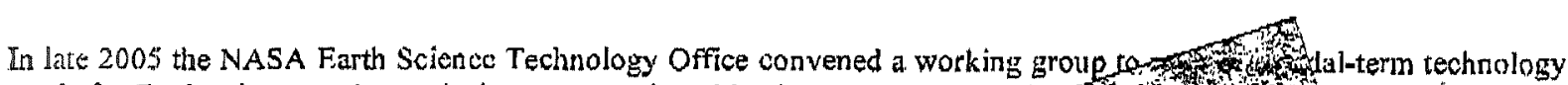
needs for Earth science active optical rcmote sensing objectives. The outcomc for of

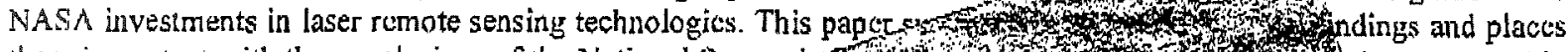

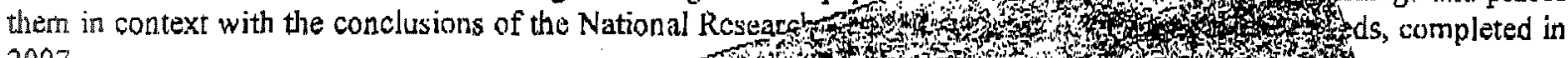
2007.

Keywords: Lidar, laser radar, laser altimetry, Ea

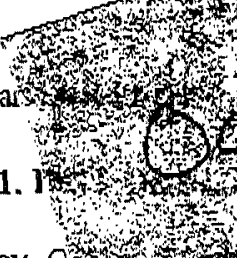

In 2003 the NASA Earth Science Technology requircments that would be necessary for mountins formulated. The resulting report idcntified and quantifing them to this future scicnce measurcments that were $t$ technology focus areas:

- Active Remote Sensing I (laser radar/lidar technol

- Active Remole Sensing 11 (radar technologies)

- Passive Remolc Sensing I (optical technologies)

a Passive Remote Sensing 11 (microwave and radio-fre

In-sin, unconventional, and non-spacebased sensing to
\end{abstract}

Since the publication of the original report, a scries of technology specific working groups has been established to dclve deeper into the requirements of each individual technology focus area and provide explicit recommendations for infusion into uture ESTO research and development solicitations. The working group that was convened to evaluate laser sensing tcchnologies had the advantage of carrying out its task within the timctrame of the National Research Council (NRC) decadal survey of future Earth and environmental science and applications needs, which was commissioned jointly by NASA, the National Oceanic and Atmospheric Administration (NOAA), and the U.S. Geological Survey in 2004. Because of this confluence, the ESTO Lidar Technology Requirements Working Group was aware of the NRC committce's measurement priorities (in terms of science impact, societal benefit, etc.) and was able to align its technology investment recommendations with those priorities. Hence, the findings contained in the Lidar Working Group report mirror to a large degrce the recommendations containcd in the decadal survey report ${ }^{3}$.

Particular attention was paid to the structure of the working group. The composition of the group included three technology subgroups focused on the topics of laser transmitters; detcction, processing and optics (reccivers); and data acquisition and utilization, while three science subgroups focused on the atmospheric composition, atmospheric dynamics, and oceans and topography application areas.

In order to capture rclevant information liom the widest possible knowledge basc, inputs from the broader external scicnce and technology communities beyond the working group membership werc solicited by means of an opcn 
Community Forum which was held carly in the process. Information acquired through this mochanism ${ }^{4}$ was then incorporated into the technology evaluation and roadmapping development.

\section{METHODOLOGY}

The exhaustive technology requirements definition process commenced with an evaluation of the science requirements, as extracted from the NASA Earth Scicnce Research Strategy document. From this a set of measurement scenarios and use cases were dorived from which technology challenges could be identified and flowed down ultimately to a roadmap timeline of priority tcchnology developments. This progression is topresented in Figure 1.

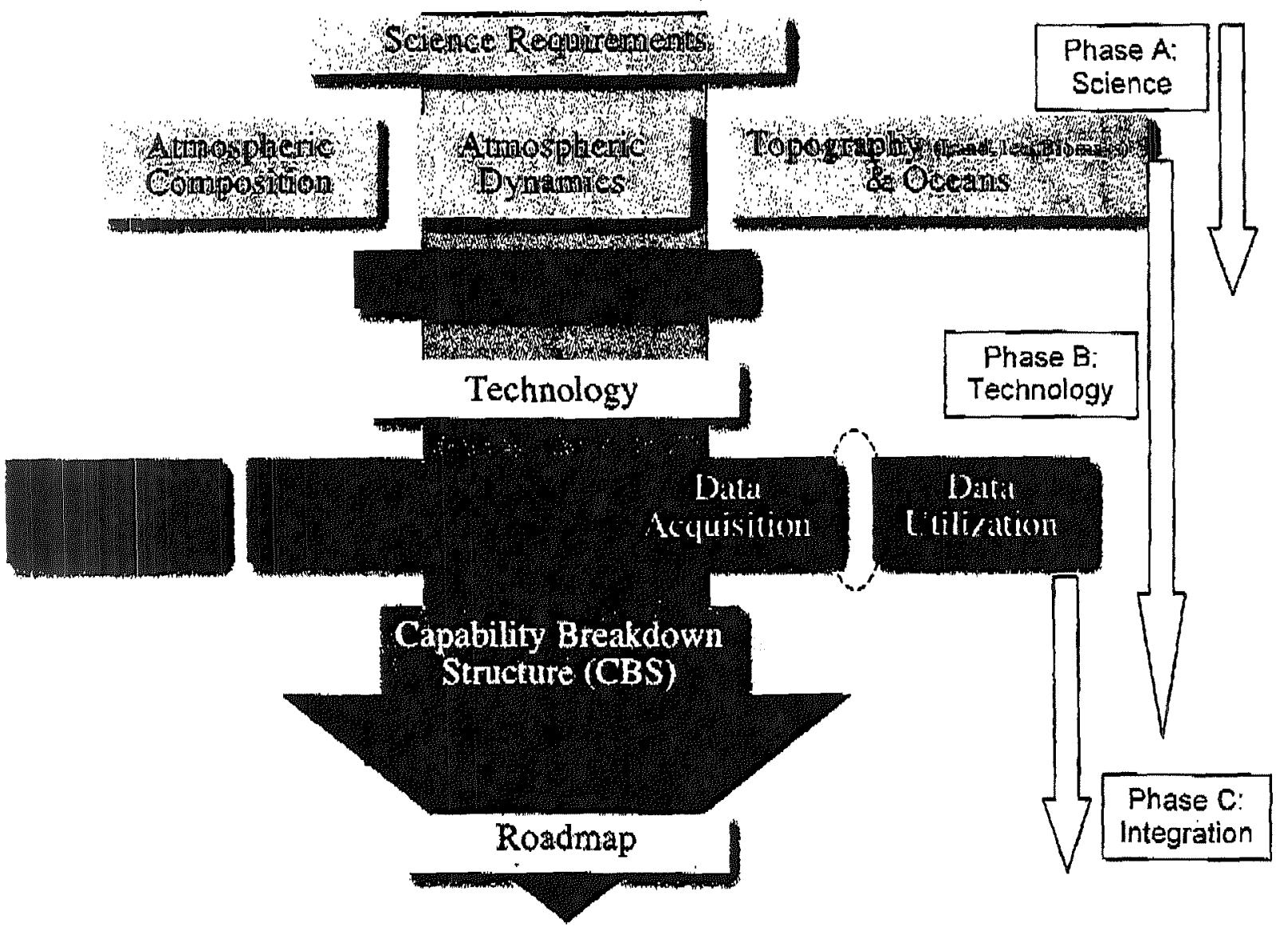

Fig. 1. Schematic depiction of the tcchnology requirements detinition process.

Whon recommending development timelines or immediacy of technology investments, the group took several priotitization factors into account. The prioritization criteria doveloped by the working group are as lollows (in order of assigned importance):

Scientific impact

- Societal bonefit

- Measurement scenario utility

- Technology development criticality

- Technology utility

- Required measurement tineline

- Mission risk reduction 
Herc, we treat only thc three highest priority criteria and refer the reader to the working group report for a discussion of the rcmaining criteria ${ }^{2}$.

\subsection{Seientîinc Impact}

Scientilic impact is defined as the degree to which the proposed measuroment vio lidar technique will improve our scientific understanding of the Farth Systcm and help to answer the overarching questions explicit in the NASA Earth Science Research Strategy. The key factor to consider here is the seientific impact achieved because of the uniqueness' of the lidar measurement technique. Lidar techniques make significant and unique contributions to our scientific understanding specifically for the following measurements:

- Tropuspheric Winds, where timely mesurement on a global scale is impossible using any other currently known methodology. Yet, and despite its acknowledged importance, measurement of the 3D tropospheric wind field globally from space has remained an elusive goal. High spatiotemporal resolution knowledge of the tropospheric wind held is vital for understanding the weather system and for accurate prediction of severe wealher events such as hurricaness.

- Tropospheric $\mathrm{CO}_{2}$ Profile, where the desired horizontal and vertical tesolution is not feasible with any other technigue than active optical sensing. Determining the $\mathrm{CO}_{2}$ profile in the atmosphere will have a major impact on our understanding of changes in this primary greenhouse gas and its impact on the Earth system. In order to properly characterize the magnitude and location of $\mathrm{CO}_{3}$ sources and sinks, it is essential to acquire high resolution measurements within the lowermost layers of the atmosphere, i.e., the planetary boundary layer and free tropospheré.

- High Resolution Ice Shear Topography and Velocity, where the value of high vertical resolution laser altimetry has been amply demonstrated by the ICESat (Ice, Cloud, and land Elevation Satellite) mission. Complemented by Interlcrometric Synthetic Aperture Radar (InSAR) to measure the flow of the ice sheet. together these medsurements have tremendous impact on our understanding of the Earth's long-term climale and implications for the Earth's changing sea-levels, which can threaten coastal areas'.

- Vegetation 3D Structure, Biomass and Disturbance, whcre lidar systems offer very high range resolution conpared to either passive electro-optic or microwave techniques. High vertical resolution measurements are key to accurate profiling of the vegelation canopy and the assessment of change in forest structurc ${ }^{8}$.

- Phytoplankton Physiology, where lidar is expected to play an important role, providing both primary/nuvel measurements as well as working in concert with other types of observations applicable to solving major ocean carbon cycle and biogcochemistry questions.

\subsection{Societal Benefit}

Socictal bencfit ean be judged by the degree to which the proposed measurement has the potential to improve life on Earth (e.g., uscd to improve the accuracy of natural disaster predictions). A primary intent of the NASA Earth Science Division is invesment in Earth seience application areas with clear benefit to mankind, since science rescarch to improve life on Earth has been a high priority of NASA and is explicitly stated in its charter.

Recent natural disaster cvents in the U.S. and the world at large have made it clear thar the ability to predict the onset and progress of severe weather cvents is not only critical for improving the quality of life on Earth, but also is now recognized as important to national security (as evidenced by the 2007 U.S. Congressional call for a National Intelligence Estimate on this topic'). For example, the landfall of Hurricane Katrina (2005) noloriously resulted in at least 2000 fatalities, displaced many thousands morc, and threatened the oil refineries in the Gulf of Mcxico region, thereby causing severe adverse cconomic consequences as well as exposing the vulnerability of the U.S. homeland securily systcm. liad accurate and advanced hurricane path and intensity forecasts been availablc, some of thesc extreme adverse consequcnces could havc been avoided, or at lcast mitigated, through the issuance of timely warnings.

a Our top two prioritization criteria (scientific impact and societal bencfit) accard with the top two criteria applied by the Decadal Survey committee. 
In this particular regard, accurate knowledge of the 3D global tropospheric wind ficld is essential for accuratc numerical weather forecasting and severe wcather prediction capability ${ }^{10}$. For this reason, obtaining the topospherie wind profiling capability offers arguably the most immodiute societal benefit.

A series of Observing System Simulation Experiments (OSSEs) carried out at NASA Goddard Space Flight Center, the Nalional Centers for Environmental Prediction, and the NOAA Forecast Systems Laboratory have shown that accurately measuring the global wind field will have a major impact on numerical weather forecast skill at both regional and synoptic scales". Measurcmont of global wind protiles has been recognized as the greatest unmet observational requircment for improving wcather forecasts by the World Meteorological Organization, the large collection of nations planning the Global Earth Observation System of Systems, the NOAA Integrated Program Office, and NASA in its Weather Rescarch Roadnap. In addition, improved wind mcasurements would dircelly support the missions of DOD, FAA, EPA, IEMA, DOT, DOE, USDA, and DHS.

In addition to the benefit for weuther forecasting, accurate measurement of the three-dimensional global wind field wil] allow major advances in our understanding of a host of key climate change issues such as: 1) improved knowledge of the vertical and horizontal tranisport of water vapor to verify the pcrformance and integrity of climate models and to better understand the impact of deforestation on rainfall, 2) more accurate partitioning of the heat transport by occanic and atmospheric components of the Earth system, 3) improved understanding of the sources and sinks of atmospheric $\mathrm{CO}_{2}$ which is currently based on the a priori specification of the wind ticld, and 4) improved understanding of long-range transporl of aerosols and trace gases to assess the climatic impact they may have on regional and global scales.

To assess changes in the Earth's longaterm climate, accurate measurements of $\mathrm{CO}_{2}$ column, changes in the ice shcet mass balance, and $3 \mathrm{D}$ changes in the forcst structure are also of high priority. In particular, advancing space-based $\mathrm{CO}_{2}$ profiling capability is one of the main goals of the U.S. Climatc Change Science Program.

\subsection{Moasurement Scenario Utility}

If a lidar approach was identified as the primary or unique approach for making the proposed measurement, thon this was a kcy determinant in establishing the fundamental utility of a given measurement scenario. Another important factor was whether the scenario met or exceeded threshold or goal science requirements, or otherwise met the requirements for a demonstration mission. Using these criteria as a filter, the following measurements emerged as priority applications:

- Tropospheric Winds

- $\mathrm{CO}_{2}$ Vertical Profile

Vegetation Biomass

- High Resolution Ice Surface 'l'opography

- Phytoplankton Physiology and Hunctional Groups

- Ocean Carbon/Particle Abundance

w Terrestrial Gravity Field

"Terrestrial Reforcnce Frame

The valuc of lidar for scveral of these spplications has already been discussed above. For the remaindor, we note that lidar is required for ocean carbon/particle abundance because passive imaging alone does not provide accurate retrievals of particle scattering coefficients when there is a signilicant absorbing acrosol load - a particular problem in constalcontinental shelf zones. The improved spacceraft-to-spacceraft range measurements provided by free-spacc laser interferometry applied to a next-gencration GRACE (Gravity Rccovery and Climate Experiment) "type mission are desired to criable Earth gravity field obscrvations to less than $100-\mathrm{km}$ grid $5 c a l e$ and 10 -day resolution with an accuracy of less than $1 \mathrm{-cm}$ equivalent surface water hoight ${ }^{\mathrm{b}}$. An improved satellitc laser ranging notwork will provide a factor of $\hat{\$}-10$ improvement in Earth reference frame knowledge and satcllite precision orbit determination over current capability.

\footnotetext{
${ }^{b}$ Current GRACE Ka-band observations are $-400-\mathrm{km}$ and 30 -day resolution with an accuracy of approximalely $2-3 \mathrm{~cm}$ equivalent surface water height.
} 
1. Technology Development Criticality: Whether the development of the proposed technology enables new measurement capabilitics or provides incremental improvemont in the measurement quality.

2. Technology Utility: The degree to which the technology makes a significant contribution to more than one measurcment application. The utility can be mcasured by the number of different messurement scenarios the technology enables.

3. Measurement Timeline: Determincd by the time horizon when a particular measuremcnt is needed, as articulatcd in the NASA Larth Science Research Strategy.

4. Risk Reduction: The degree to which the new technology mitigates the risk of mission failure.

\section{TECHNOLOGY REQUIREMENTS}

The working group considered individual system requirements on a holistic level, including science impacts and end-1ocnd technology needs. One expression of this policy was that information system lechnolony needs wite evaluated in tandem with the scnsor technologies, so that three separate technology subgroups wcre tasked with collating data on laser transmitter technologies, receiver tcchnologies, and information system technologies. The top-lcvel prioritized technology summaries and associated derived performance requirements now follow.

\subsection{Prinritized Transmitter Technolugy Needs}

An overvicw of the transmitter technology prinrities is given in Figurc 2. Here, each technology is traced to the moasurement application, outlining different transmitter technology options required for each application. The highest priority technologies in this area are then classified as follows:

1. 1-100W 0.1-50 mJ. 1-Lm Laser: These low pulse energy, modcrate-to-high pulserate systems are oriented toward applications for ice surface topography and 3-D vegetation structure.

2. $100 \mathrm{~W}$. $100 \mathrm{~Hz}_{z_{1}}$ l-um Laser: These high pulse energy, low pulserate systems are essential for tropospheric wind measurement (direct detection Doppler retrieval), ice mass, and phytoplankton physiology measurement applications.

3. 1-100 W/.5-um Fiher I-aser: These systems have heritage in the telecom industry and arc primarily desired for lower tropospheric $\mathrm{CO}_{2}$ measurcment. Howcver, a limited number of these systems have been space qualified, although their in-space performance and reliability statistics are minimal.

4. 5-20 W 2-um Laser: These systems are applicable to tropospheric vector wind (coherent Doppler retrieval) and lower tropospher ic $\mathrm{CO}_{2}$ measurement.

5. Wrvelength Converters: These systcms are essential for direal detection Doppler wind, icc mass, $\mathrm{CO}_{2}$, and phytoplanklon physiology measurements. This category includes target wavelengths in the UV, visible, and shorwave-IR spectral regions.

6. Beam Dircetor: Reliablc, repeatablc, high-slewrate bean scanning technologies are cssential for the tropospheric vector wind and 3-D biomass vegetation structure missions. 


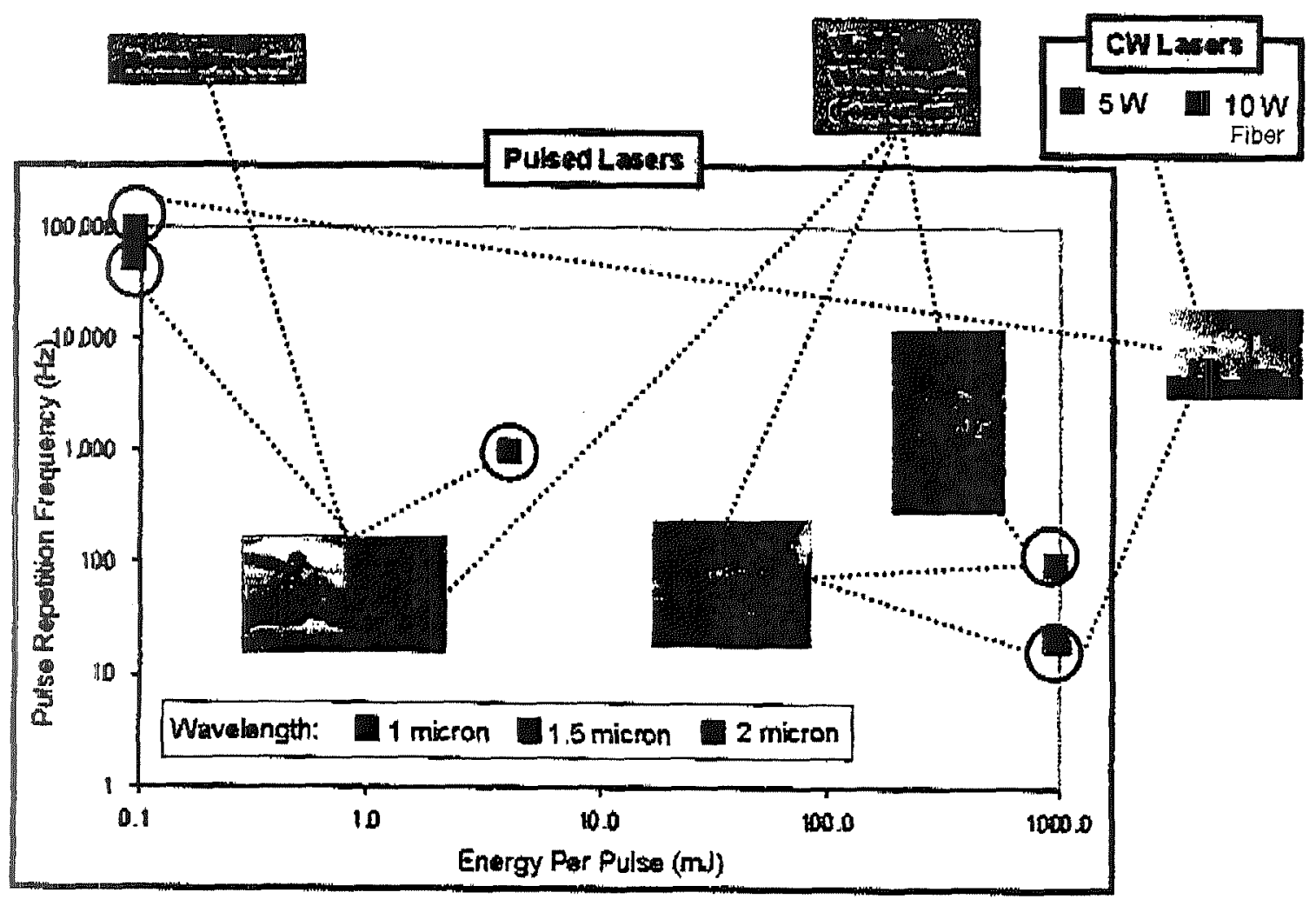

Fig. 2. Transmiller technology scicnce applications summary and llowdown to performance requirements,

\subsection{Prioritized Receiver Technology Needs}

Iligh priority tcceiver technologies arc summarized in Figure 3 , in which each technology is again traced to the measurement application, outlining different receiver technology options required lor each application. The highest priority receiver technologies are classified accordingly:

1. Alignment Maintenance: This technology is essential for tropospheric winds. The requirement varies for different measurements and varies from approximately 5-50 mrad.

2. Sccanning Systems: Technologies are needed to extend the field of regard of the receiver beyond a single bean fixed pointing system. This is an essential technology for tropospheric wind and 3D biomass measurements.

3. Large Lighlweight Telescopes $\left(<25 \mathrm{~kg} / \mathrm{m}^{2}\right)$ : Telescope apertures in the range $1-2 \mathrm{~m}$ in diameter arc required for ecrtain altimetry measurements. Aperturcs up to $3-\mathrm{m}$ diameter are required in the case for $\mathrm{CO}_{2}$ and phytoplankton physiology measurements.

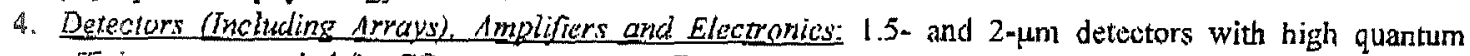
efficiency are needed for $\mathrm{CO}_{2}$ measurements. Thesc technologics will also permit rclaxation of laser powcr requirements. Next generation high-speed analog-to-digital converters are needed for altimetry measurcments.

5. Optical Filters and Specialo Opics: Special requircments in this technology class enable $\mathrm{CO}_{2}$ and phytoplankton measurements. 


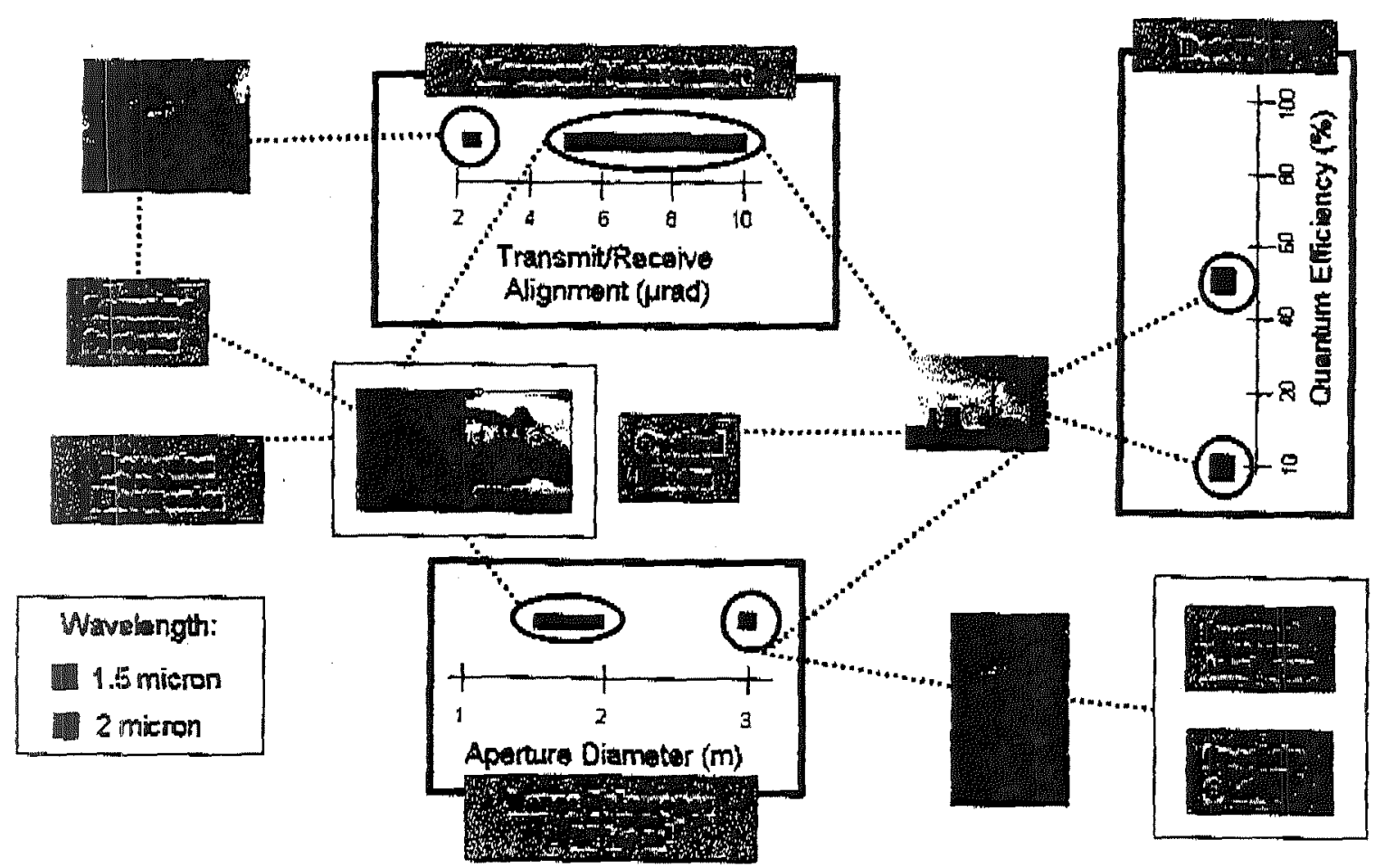

Fig. 3. Receiver tcchrology science applications sumenary and flowdown to perlomance requirements.

\subsection{Prioritized Information System Technology Needs}

In Figure 4 priorily technologies are mapped against representative science scenarios and illustrated with requirements for data processing time and data volume. Each color-coded box in the three data acquisition and utilization (DAUJ) technology tables represents a specific priority technology. The accompanying graphs indicalc ranges of requirements for data processing time and data volume for each lcchnology area. In addition, each technology is traced to the measurement application, outlining different choices of DAU tcchnologies for oach discrete application. The highest priority technologics in this area are classificd according to:

1. Airborne/Ground Vulidation Systems: Rapid calibration and validation of data is nceded for a varicty of purposes such as improving weather forecast models, and quantifying the instrument performance degradation over time. OSSFs (Observing System Simulation Experiments) are an important component of this enabling technology. This technology benefits ice mass, 3D biomass, and phytoplankton physiology measurements.

2. Intelligenl Sensor Heallh and Safety: Lidars with high power and high pulserate or high degree of alignment stability greatly bencfit from this technology intended to increase lidar life. Biomass and $\mathrm{CO}_{2}$ measurement greatly benefit from this technology due to the nature of lidar used.

3. Scicnce model-driven adaptive largeting: In order to meet stringent time requirements, especially for weather forcasting, autonomous methods to identify targets and commund the spacecraft are necessary to fll data gaps for a decision support system. Without model-driven data gap identification, weather relalcd mission goals are not achicvable. This techology also applies to $\mathrm{CO}_{2}$ measurcment. Although seven prioritics were identilied, we address only four areas here, since storage, processors, and on-board
computing technologies arc already either funded under existing programs or are currently boing advanced by industry. 
4. On-board Senisor Control: This type of technology is needed for autonomous data acquisition based on a set of defined conditions (e.g., cloud-free linc-of-sight) and for instrument calastrophic failure avoidance. This rechnology is relevant to ice mass and $\mathrm{CO}_{2}$ measurement.

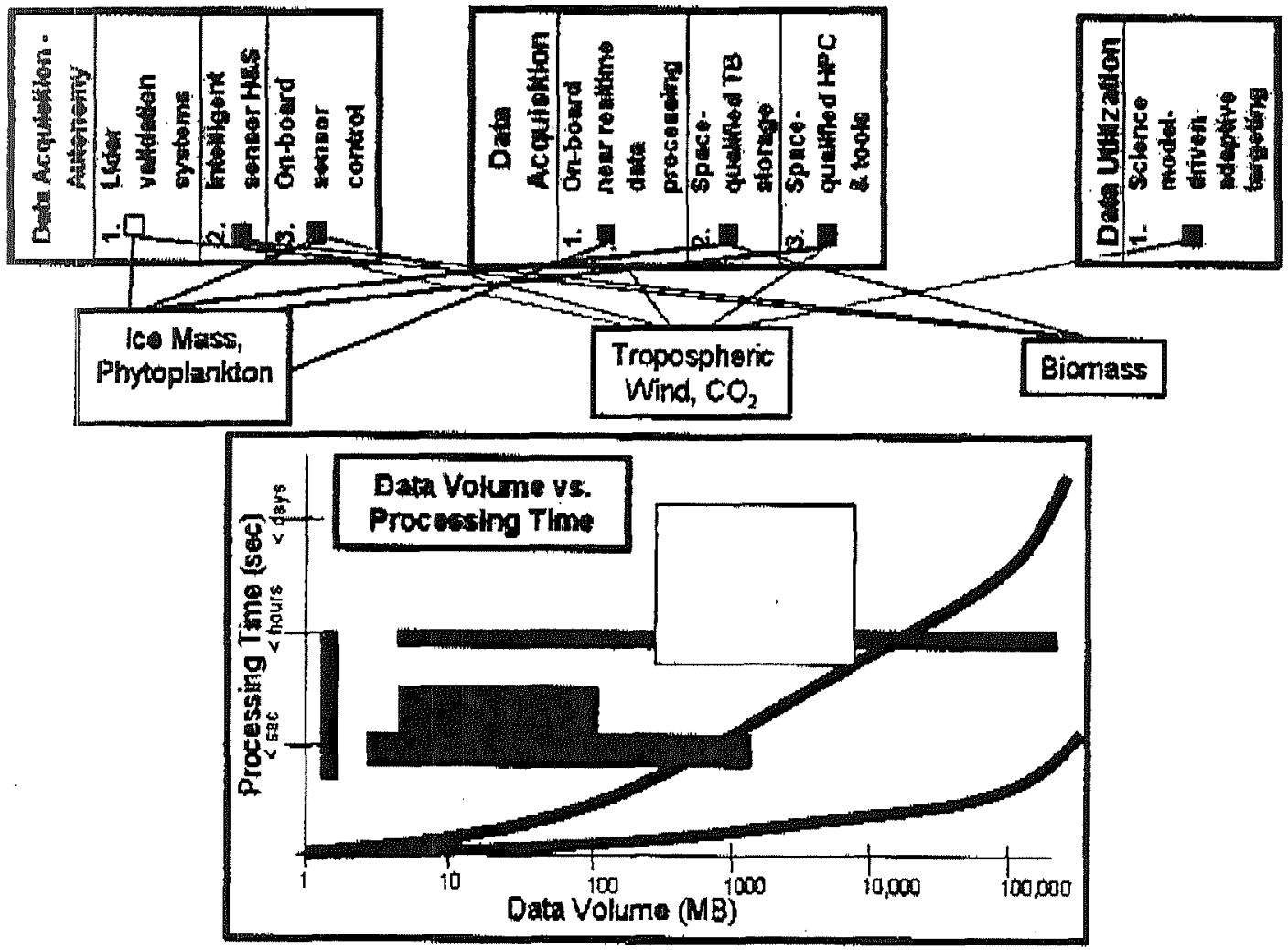

Hig. 4. Information system technology science applications summary and flowdown to performance requirements.

Three distinct timing requircments for information processing needs were identified:

1. Real time requirement-based on an on-board processing architecture to achieve instrumcnt pointing control and a real-time sensor web lor on-the-fly data calibration/validation.

2. L-hour requirement-based on a spacecraft and instrument command and sequence ground operation system. Requirement addresses timely delivery of ancillary data to validate and calibratc weather related data and provide to a weather forecasting system in 3 hours.

3. 3-hour requirement- based on cooperating science ground data systems 10 support a decision support systcm. Requirement addresses data production and managenent, data assimilation, and intertaces to mission operations and model forecasling systems.

\section{RELATIONSHIP TO 2007 EARTH SCIENCE AND APPLICATIONS DECADAL SURVEY}

\subsection{NRC Decadal Survey Conclusions}

The NRC Earth Science Decadal Survey report recommends 3 missions for execution by NOAA and 14 by NASA ${ }^{3}$ with mission implementation timelines ranging from the near-torm (2010-2013), to mid-term (2013-2016), and finally to tho long-term (2016-2020). Of the 17 recommended Earth science missions, six stipulate a requirement for laser remote sensing technology and one retains laser sensing as an option: 
- ICFSat-II to measure ice shect topography changes for climate change diagnosis using a laser altimeter (near-term).

- DESDynl (Deformation, Ecosystem Siructure, and Dynamics of Ice) to measure surface and ice shcet deformation for understanding natural hazards and climate, and vegetation structurc for ecosystem health using a laser altimeter and an L-band InSAR (near-term).

- AsCENDS (Aclive Sensing of $\mathrm{CO}_{2}$ Emissions oyer Nights, Days, and Seasons) lor measuring diumal, alllatitude, all-season $\mathrm{CO}_{2}$ column-integrated moasurements for climate emissions diagnosis using a multifrequency laser (mid-term).

- ACE (Aerosol/Cloud/Ecosystem) for measuring acrosol and cloud profiles for understanding of climate change and the water cycle using a backscatter lidar (mid-term).

- LIST (Lidar Surface Iopography) to measurc land surface topography for landslide hazards and water runoff using a laser altimeter (long-term).

- GRACE-II to measure high temporal resolution gravity fields for tracking large-scale watcr movement using spacecraft-to-spacecraft laser (or microwave) ranging (long-term1).

IB $3 \mathrm{D}$-Winds to map tropospheric wind vector profiles for weather forecasting and pollution transport (longtem).

It is important to recognize that many of the same technologies are applicable to planetary and lunar science measurements. This speaks to the importance and growth of laser remote sensing in the next few decades.

\subsection{Intersection of Working Group Findings with Decadal Survey Recommendations}

The FSTO Lidar Working Group final teport ${ }^{2}$ was relcased approximately six months prior to publication of the Earth Scicnce and Applications Decadal Survey report and recommended technology development for the following measurements that overlap with the missions recommended by the Decadal Survey:

- Tropospheric Winds (designated 3D-Winds by the Decadal Survey). The ESTO group recommended immediate technology development in this area to address the technology challenges associated with this measurcment. This is in concurrence with the decadal survey recommendation of a demo $3 \mathrm{D}$-wind demo mission by 2016 , since the technology development requircs a maturing phase to approach readiness for space flight. However, we stress that investments in the hybrid (direct and coherent detection) approach ${ }^{\text {t2 }}$ must begin immediotely in order to make the 2016 launch feasible.

- Ice Mass (designated ICESat-II by the Decadal Survey). The group recommended technology developments for improving the measurements already achicved by TCESat $^{13}$ for a mid-term implementation. However, it is clear from the decadal suivey report that the panel favors flying an ICESatIl mission in the near-term with little or no modification to the technology alrcady flown. In this case, the technology development investment would be minimal to fly what would essentially be a re-build of ICESat

- $\mathrm{CO}_{2}$ (dcsignated ASCENDS by the Decadal Survey). The working group recommended investment in a set of competing technology approachcs and a trade study to mature the most promising technology.

- Biomass (designated DFSDynI by the Decadal Survey). The working group rocommended investnent in technologies for the vegetution laser altimcter for a longer term implementition than that indicated in the decitdal survey.

The technology recommendations cmanating from the LSTO working group report thus have the potential to enable 7 out of 17 (or $40 \%$ ) of the missions rccommended by the Earth Science Decadal Survcy report.

\section{THE PATH FORWARD AND FOLLOW-ON ACl'IVITIES}

In response to the Earth Science Decadal Survey recommendations, NASA hus convened a series of working groups charged with defining high fidelity requircments for the four missions that the survey panel urged be executed in the near-tcrm (2010-2013). Two of these involve laser remote sensing (i.e., ICESat-II and DESDynI) and stand to gain immediate benefit from the Lidar Working Group's efforts. 
Whilc the Earth Science Decadal Surycy recommended that the 3D-Winds demonstration mission not be considered for implementation until the long-tcrm (i,e, 2016-2020), NASA and NOAA nevertheless recently formed a joint working group to tightly coordinate focused technology development for research leading to an operational mission. This effort is expected to aggressively leverage wehnology from industry and other U.S. government programs.

Progress achieved by related international programs, in particular the European Space Agency's Earth Explorer Atmospheric Dynamics Mission (ADM-Aeolus) development ${ }^{14}$, offer scope for future collaborative opportunities in global laser remote sensing. This would further build on the fruitful relationship exemplified by the joint NASA/Centre National d"Eudes Spatiales CALIPSO (Cloud-Aerosol Lidar and Infrared Pathfinder Satellite Observations) mission, which is a multi-instrument Farth-orbiting platform that includes as its conterpiece a two-color polarimetric acrosol/cloud profiling lidas ${ }^{15}$.

\section{ACKNOWLEDGEMENTS}

The work summarized in this paper is the result of a lengthy effort by a large interdisciplinary team of scientists and technologists whose diligence and dedication to the task was essential to its success. A full listing of the working aroup participants is given in the final report document'. A particular debt of gratitude is owed to George Komar, Deputy Associate Adninistrator for Technology of the NASA Science Mission Directorate (2006-2007), who originally chartered the ESTO Lidar Technology Rcquirements Working Group.

\section{REFERENCES}

1. A. Valinia, J. Neff, R. Kinsey, and D. Tratt, "Sensor and platlorm technology requirements for implementing NASA" Earth science research strategy in the ncxt decade" (NASA Farth Science Technology Office, 2003), tritp://estips.gsfc.nase.gov/Home/docs/ESTOWorkhop2003I.pdf.

2. J. Hyon, S. Gasster, I. Neff, A. Gillam, K. Moe, D. Trath, and A. Valinia, "Working Group Report: Lidar "lechnologies" (NASA Earth Science Technology Office, 2006), http://esto.nasa.gov/filcs/L.WGRcport2006.pdf.

3. National Rescarch Council, Committee on Earh Science and Applications from Space, Earth Science and Applicaitions from Space: National Trperatives for the Next Decade and Beyond (National Academies Pross, Washington, DC, 2007), http://www.nap.edu/catalog/] 1820.html.

4. NASA ESTO Lidar Community Forum Submissions (NASA Farth Science Teclanology Officc, 2006), http://esto.nasa.gov/tiles/LWGRepon2006. Appondix7.pdf.

5. R.M. Atlas, G.D. Emmitt, J. Torry, E. Brin, J. Ardizzone, J.C Jusem, and D. Bungato, "Potential impact of spacebased lidar wind profiles on weather prediction," Proc. SPJE, 5154, 74-78, doi:10.1117/12.503859, 2003.

6. D.M. Etheridge, L.P. Stecle, R.L. Langenfelds, R.J. Francey, J.-M. Barnola, and V.I. Morgan, "Natural and anthropogenic changes in atmospheric $\mathrm{CO}_{2}$ over the last 1000 years from air in Antarctic ice and firn," J. Geophys. Res, $101,4115-4128$, doi: $10.1029 / 95$ JD03410, 1996.

7. H.J. Zwally, M.B. Giovincto, J. Li, H.G. Comejo, M.A. Becklcy, A.C. Brenner, J.L. Saba, and D. Yi, "Mass changes of the Groenland and Antarctic ice shects and shelves and contributions to sca-level rise: 1992-2002,"J. Glaciol., 51, 509-527, 2005.

8. D.J. Harding, J.B. Blair, J.B. Garvin, and W.T. Lawrence, "Lasers allimetry waveforn measurement of vegetation canopy structure," Proc. International Guoscience and Remote Sensing Symposium (TGARSS '04), Vol. 2, 12511253, doi:10.1109/GARSS.1994.399398, 1994.

9. Introduction of the Global Climate Change Security Oversight Aot (United States Senate Bill S.1018), Congressional Record (Senate), March 28, 2007, pp. \$4059-\$4061.

10. W.E. Baker, G.D. Emmitt, F. Robertson, R.M. Atlas, I.E. Molinari, D.A. Bowdle, J. Paeglc, R.M. Hardesty, R.T. Menzies, T.N. Krishnamurli, R.A. Brown. M.J. Post, J.R. Anderson, A.C. Lorenc, J. McElroy, "Lidar-measured winds from space: A key componcent for weather and climale prediction," Bull. Amer. Meleorol. 5oc., 76, 869-888, doi:10.1175/1520-0477(1995)07600869:LMWFSA $=2,0 . C 0 ; 2,1995$.

11. B,D. Tapley, S. Bettadpur, M. Watkins, and C. Reigber, "The gravity recovery and climate experiment: Mission overvicw and early results," Geophys. Res. Lett., 31, L09607, doi:10.1029/2004GL019920, 2004.

12. G.D. Emmitt, "Combining direct and coherent detection for Doppler wind lidar," Mroc. SPIE, 5575, 31-37, dois $10.1117 / 12.576539,2004$. 
13. B.F, Schutz, H.T. Zwally, C.A. Shuman, D. Hancock, and J.P. DiMarzio, "Overview of the ICESat mission," Geophys. Kes. Lett, 32, L21S01, doi:10,1029/2005GL024009, 2005.

14. A. Stuffelen, J. Pailleux, E. Källén, J.M. Vaughan, L. Isaksen, P. Flamant, W. Wergen, E. Andersson, H. Schyberg, A. Culoma, R. Meynarl, M. Endemann, and P. Ingmann, "The Atmospheric Dynamics Mission for global wind ficld measuremcnt," Bull. Amer. Melcorol. So6, 86, 73-87, doi:10.1 175/BAMS-86-1-73, 2005.

15. D. Winker, M. Vaughan, and W. Hunt, "The CALIPSO mission and initial results from CAIIOP," Proc. SPIE, 6409,640902 , doi:10.1117/12.698003, 2006. 